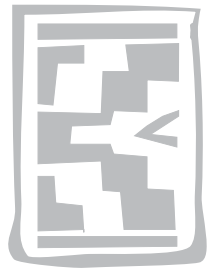

\title{
Nematode parasites of Clarias gariepinus (Burchell, 1822) from the Rietvlei Dam, South Africa
}

\author{
M. BARSON ${ }^{1,2}$ and A. AVENANT-OLDEWAGE ${ }^{1}$
}

\begin{abstract}
BARSON, M. \& AVENANT-OLDEWAGE, A. 2006. Nematode parasites of Clarias gariepinus (Burchell, 1822) from the Rietvlei Dam, South Africa. Onderstepoort Journal of Veterinary Research, 73:87-94

Catfish, Clarias gariepinus, from the Rietvlei Dam near Pretoria, South Africa were examined for nematode parasites. Two species, Procamallanus laeviconchus in the stomach and Contracaecum spp. larvae in the abdominal cavity, were found. The morphology of these species, based on light and scanning electron microscopy, and how they compare with previously described specimens are discussed. Infection rates were mild compared to previous surveys although Contracaecum spp. had a high prevalence of $86 \%$.
\end{abstract}

Keywords: Clarias gariepinus, Contracaecum, nematode, parasite, Procamallanus, Rietvlei Dam

\section{INTRODUCTION}

The study of parasitic diseases of fish and other aquatic organisms in South Africa only started to gain attention over the past few decades as scientists began to realise their significance in fisheries and aquaculture (Safriel \& Bruton 1984; Hoffman \& Prinsloo 1996). Only a few researchers have published their work on nematode parasites in the country, and these include Prudhoe \& Hussey (1977), Mashego (1977, 1982), Mashego \& Saayman (1981), Boomker (1982, 1994a, b), Saayman, Mashego \& Mokgalong (1991) and Mokgalong (1996). The results of this study will contribute to this existing body of knowledge.

1 Department of Zoology, University of Johannesburg, Kingsway Campus, P.O. Box 524, Auckland Park, Johannesburg 2006, South Africa

2 Author to whom correspondence is to be directed. E-mail: barson@science.uz.ac.za. Present address: Department of Biological Sciences, University of Zimbabwe, P.O. Box MP 167, Mt Pleasant, Harare, Zimbabwe

Accepted for publication 10 January2006-Editor
The sharptooth catfish, Clarias gariepinus (Burchell, 1822), the host species investigated in this study, is widely distributed in Africa (Safriel \& Bruton 1984; Skelton 2001) and is an excellent species for aquaculture and biological research (Hoffman \& Prinsloo 1996).

The study was carried out as a reconnaissance survey of the internal parasites that are found in C. gariepinus from the Rietvlei Dam, which can be used in the fish health assessment index that has been developed for South African fish by Avenant-Oldewage (2001). The objectives of this paper were to specifically identify and classify the nematode parasites collected from C. gariepinus based on their morphological features, and to note their prevalence and mean intensity in the Rietvlei Dam.

\section{MATERIALS AND METHODS}

\section{Study area}

The Rietvlei Nature Reserve (2541'22" S; 26³7'48" E) lies between Pretoria and Johannesburg in Gauteng Province (Fig. 1). Developed out of the Rietvlei 
Water Scheme, it is solely responsible for conservation of the Sesmylspruit catchment area, and the Rietvlei Dam (2532'30" S; $28^{\circ} 16^{\prime} 46^{\prime \prime}$ E) currently supplies $27 \%$ of Pretoria's water requirements (Wessels 1998). A smaller dam, the Marais Dam, lies approximately $4 \mathrm{~km}$ upstream, and the two are separated by a wetland (Fig. 1). Further upstream, just before the Sesmylspruit enters the reserve, the stream receives effluent from a number of industries and a wastewater treatment plant.

\section{Field collection of fish and parasites and identification}

Fish were collected in May 2003 from the Rietvlei Dam using large mesh gill nets. The fish were dissected and the mesenteric cavity examined for par- asites. The gastrointestinal tract was then dissected from the rectum to the oesophagus and all nematodes encountered were carefully detached from the stomach or intestinal mucosa. The internal organs of each fish were also examined for parasites or cysts. The nematodes were fixed in glacial acetic acid and preserved in $70 \%$ ethyl alcohol. Some larval nematodes were stained with Horen's trichome stain according to the method of Khalil (1991). Specimens for scanning electron microscopy (SEM) examination were preserved in absolute alcohol after which they were processed for SEM as detailed by Barson \& Marshall (2004).

The parasites were identified based on their observed morphology as well as from drawings. Light micrographs were taken with a Zeiss Axioplan micro-

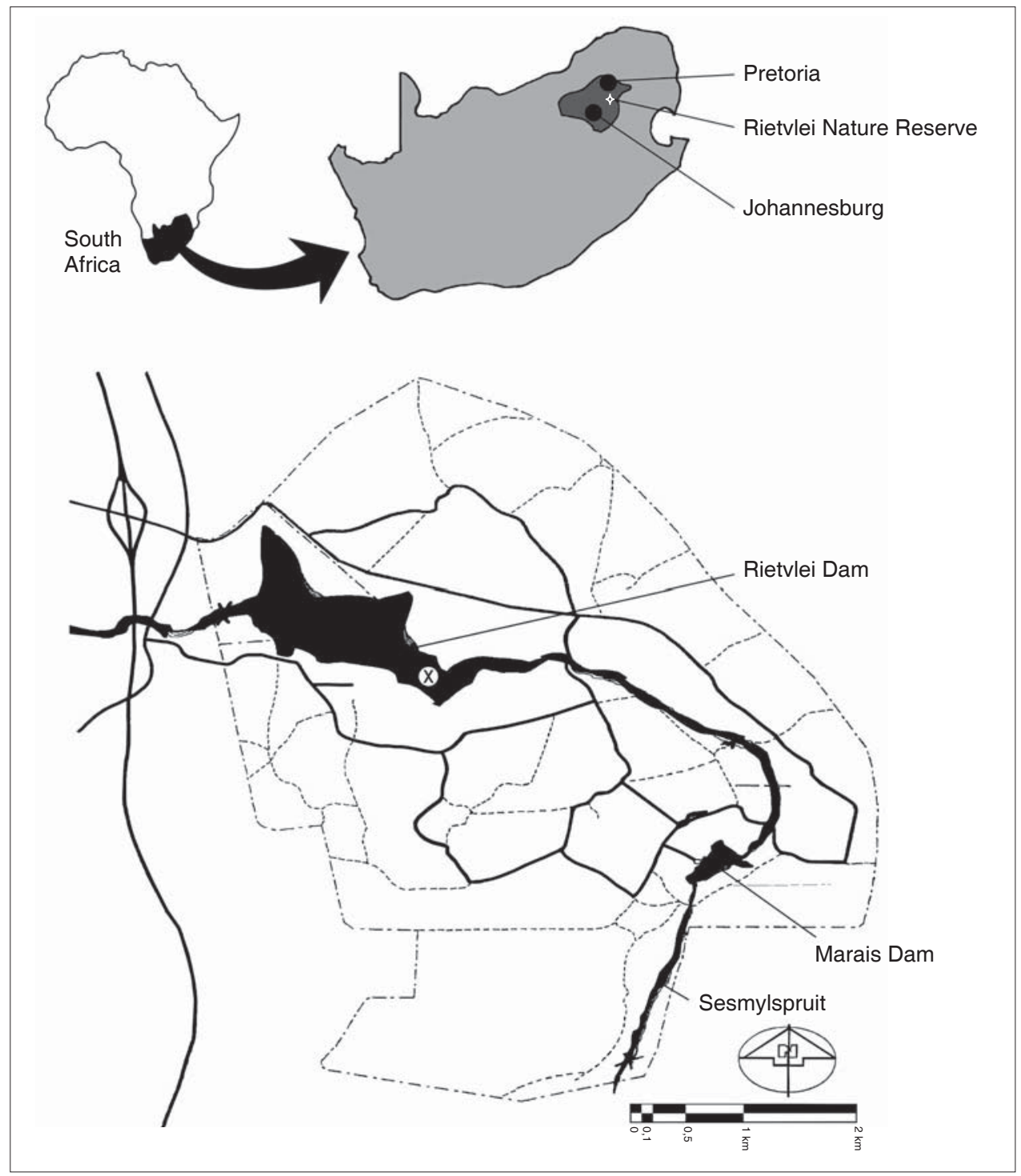

FIG. 1 The location of the Rietvlei Dam inside the Rietvlei Nature Reserve. $\mathrm{X}$ indicates point of sampling 
scope, and scanning electron micrographs with a JEOL 6100 scanning microscope. Drawings and measurements were done with a Zeiss 25 standard light microscope equipped with a drawing tube. The descriptions by Yamaguti (1961), Chabaud (1974), Hartwich (1974) and Moravec (1975) were used to aid in the identification of the parasites. Parasite prevalence and mean intensities were measured and calculated as defined by Margolis, Esch, Holmes, Kuris \& Schad (1982).

Voucher specimens were deposited in the zoological collection of the University of Johannesburg (formerly Rand Afrikaans University), South Africa.

\section{RESULTS AND DISCUSSION}

Two nematode genera were found in $C$. gariepinus from the Rietvlei Dam, namely Procamallanus laeviconchus (Wedl, 1862) and larvae of Contracaecum spp.

\section{Procamallanus laeviconchus (Wedl, 1862)}

(Fig. 2 and 3)

This is a small ovoviviparous nematode that is prevalent in most African freshwater fishes, notably in siluroids (Khalil 1970; Moravec 1975; Mashego 1977; Mashego \& Saayman 1981; Boomker 1982, 1994a,

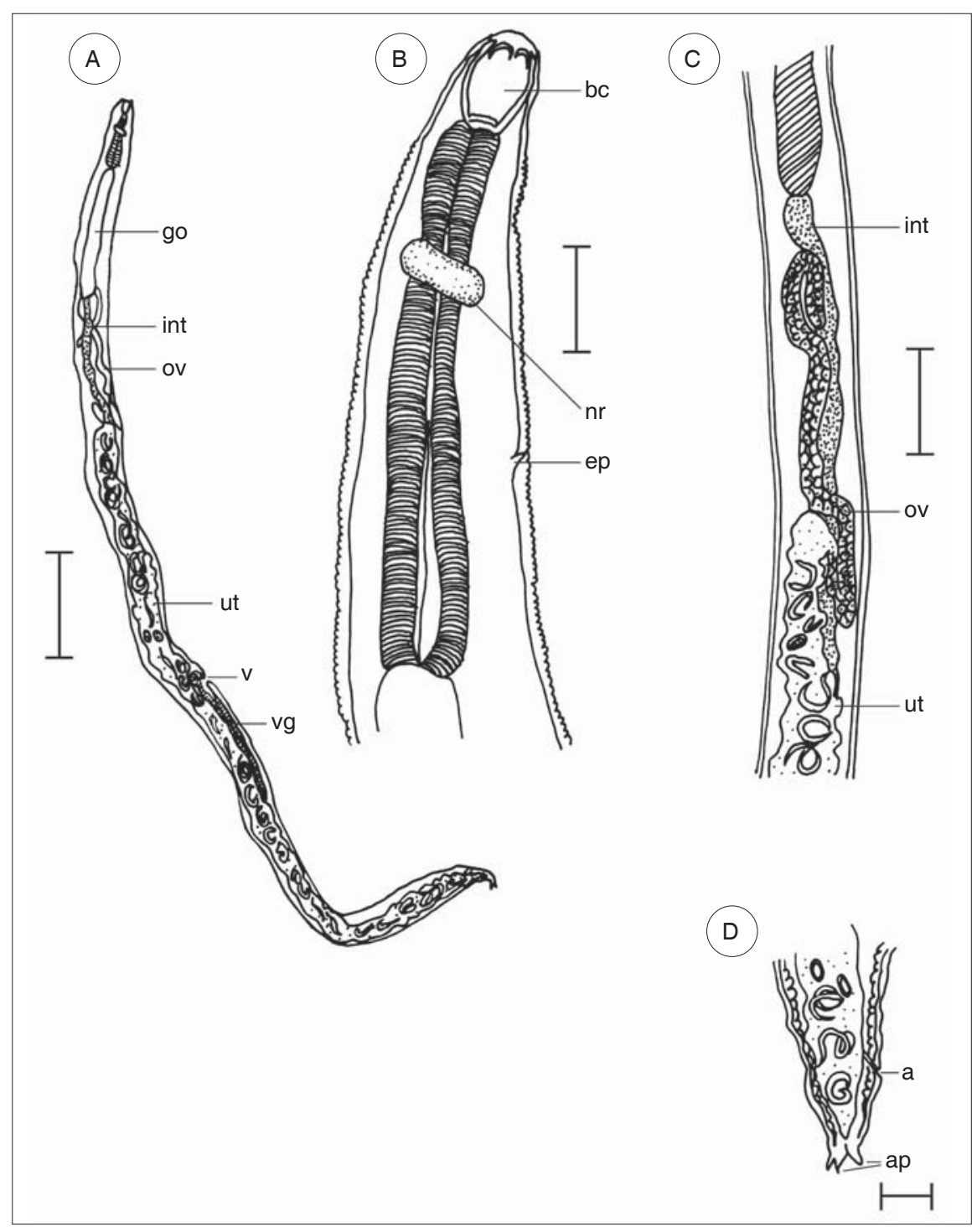

FIG. 2 Procamallanus laevionchus female drawings. (A) whole worm. Scale bar $=400 \mu \mathrm{m}$; (B) anterior end. Scale bar $=100 \mu \mathrm{m}$; (C) mid-body. Scale bar $=200 \mu \mathrm{m}$; (D) posterior end. Scale bar $=20 \mu \mathrm{m} . \mathrm{a}=$ anus, $\mathrm{ap}=$ anal (tail) processes, $\mathrm{bc}=$ buccal capsule, $\mathrm{ep}=$ excretory pore, $\mathrm{go}=$ glandular oesophagus, int = intestine, $\mathrm{nr}=$ nerve ring, ov = ovary, ut = uterus, $v=$ vulva, $v g=$ vagina 

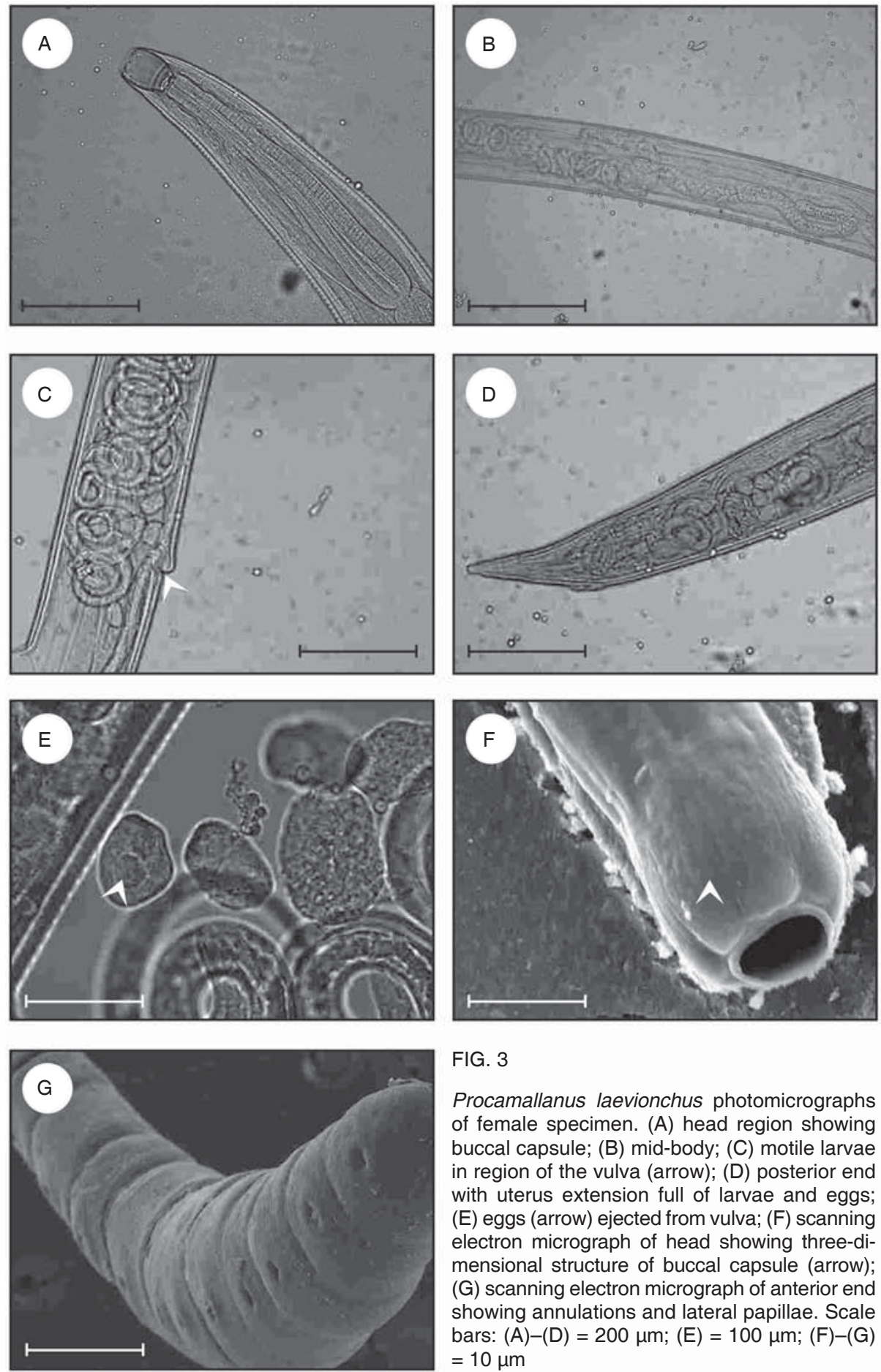

FIG. 3

Procamallanus laevionchus photomicrographs of female specimen. (A) head region showing buccal capsule; (B) mid-body; (C) motile larvae in region of the vulva (arrow); (D) posterior end with uterus extension full of larvae and eggs; (E) eggs (arrow) ejected from vulva; (F) scanning electron micrograph of head showing three-dimensional structure of buccal capsule (arrow); (G) scanning electron micrograph of anterior end showing annulations and lateral papillae. Scale bars: $(A)-(D)=200 \mu \mathrm{m} ;(E)=100 \mu \mathrm{m} ;(F)-(G)$ $=10 \mu \mathrm{m}$

b; Chishawa 1991; Saayman et al. 1991; Douëllou 1992; Khalil \& Polling 1997). One out of seven hosts was infected (prevalence 14\%) with an intensity of 13 nematodes. Only female specimens were obtained and described, most of the characteristics matching those described by Moravec (1975) and Boomker (1982). Diagnostic measurements show that the Rietvlei Dam specimens have the same size range as those described by Boomker (1982) although they were somewhat larger with respect to the distance of anus to tail and length of the glandular portion of oesophagus (Table 1).

This study additionally showed the three-dimensional aspect of the head of $P$. laeviconchus with the SEM (Fig. 3F), the buccal capsule of which still fits the 
TABLE 1 Comparative diagnostic measurements of Procamallanus laevionchus infecting C. gariepinus from the Rietvlei Dam (this study) and Hartbeespoort Dam (Boomker 1982), and in Clarias sp. from the Nile River, Egypt (Moravec 1975)

\begin{tabular}{|c|c|c|c|}
\hline Measurement* & $\begin{array}{l}\text { Rietvlei Dam } \\
\text { (2003, this study) } \\
n=7\end{array}$ & $\begin{array}{l}\text { Nile River } \\
\text { (Moravec 1975) } \\
n=8\end{array}$ & $\begin{array}{l}\text { Hartbeespoort Dam } \\
\text { (Boomker 1982) } \\
n=5\end{array}$ \\
\hline Length (mm) & $6.2-8.9(7.6)^{\star \star}$ & $3.7-7.4$ & $7.0-8.9$ \\
\hline Maximum width & $145-280(222)$ & $136-204$ & $181-216$ \\
\hline Buccal capsule length & $60-90(78)$ & $(69)$ & $83-96$ \\
\hline Buccal capsule width & $58-70(62)$ & $57-63$ & $60-70$ \\
\hline Length of muscular part of oesophagus & $380-510(441)$ & $360-516$ & $411-491$ \\
\hline Length of glandular part of oesophagus & $960-1020(983)$ & $666-990$ & $775-927$ \\
\hline Distance of nerve ring from anterior end & $105-213(173)$ & 189-207 & $208-226$ \\
\hline Distance of vulva to anus (mm) & $2.0-3.3(2.7)$ & - & $3.0-3.5$ \\
\hline Distance of anus to tail & $140-340(227)$ & - & $117-138$ \\
\hline Distance of vulva to tail (mm) & $2.4-3.4(2.9)$ & $1.8-3.0$ & $3.1-3.6$ \\
\hline
\end{tabular}

* All measurements in $\mu \mathrm{m}$ unless otherwise stated

** Mean values in parentheses

$n$ number of specimens measured

TABLE 2 Diagnostic measurements of Contracaecum sp. L3 larvae infecting C. gariepinus from the Rietvlei Dam

\begin{tabular}{|l|l|l|}
\hline Measurement & $\begin{array}{l}\text { Range } \\
\boldsymbol{n}=9\end{array}$ & Mean \\
\hline Body length (mm) & $22.0-35.0$ & 27.6 \\
Body width & $680-780$ & 710 \\
Head diameter & $120-160$ & 140 \\
Ventricular appendix length & $510-1040$ & 790 \\
Ventricular appendix width & $100-160$ & 120 \\
Intestinal caecum length (mm) & $1.24-2.2$ & 1.72 \\
Intestinal caecum width & $120-180$ & 160 \\
Length of tail from anus to tip & $130-250$ & 200 \\
\hline
\end{tabular}

* All measurements in $\mu \mathrm{m}$ unless otherwise stated

$n$ number of specimens measured

description by Moravec (1975). Microscopical observation showed three terminal tail processes (Fig 2D), but these were, however, not observed on the SEM photograph of the posterior end of the worm (Fig. 3G); the specific specimen was probably still in its fourth larval stage. Eggs and motile larvae at various stages of development were observed, some eggs having been squeezed out through the genital opening (Fig. 3B and C). Measurements of L3 larvae are reflected in Table 2

Procamallanus laeviconchus is always found deeply attached to the mucosa of pyloric region of the host's stomach wall and has been shown to cause severe pathological effects (Paperna 1996). Apart from the finding of Mashego \& Saayman (1981) who recorded a total of 23 worms in one fish, the intensity of 13 worms in one fish from the Rietvlei Dam is considerably high when compared to the low numbers recorded by Boomker (1982, 1994a) from C. gariepinus. Moravec (1975) states that $P$. laeviconchus infection is widespread in many African fish families.
In neighbouring Zimbabwe, Chishawa (1991) and Douëllou (1992) recorded it from the Clariidae and Schilbeidae from Lake Kariba. In Nigeria, Opara \& Okon (2002) reported it from Oreochromis niloticus (Cichlidae) and Yakubu, Omoregie, Wade \& Faringoro (2002) from C. gariepinus (Clariidae) and Tilapia zilli (Cichlidae). Khalil (1970) recovered P. laeviconchus from seven fish species from Ghana and belonging to the Mormyridae, Schilbeidae and Mochokidae.

The list of African helminths by Canaris \& Gardner (1967) includes Procamallanus mazabukae Yeh, 1957 infecting homa fish from Zambia and Procamallanus spiralis infecting Heterobranchus anguilaris (Clariidae) from northern Africa. The former does not, however, appear in Khalil \& Polling's (1997) updated checklists, while the latter has probably been renamed as Spirocamallanus (Santos, Cárdenas \& Lent 1999). However, other Procamallanus species in Africa are known to infect amphibians (Canaris \& Gardner 1967; Anderson 1992). Many species of Pro- 


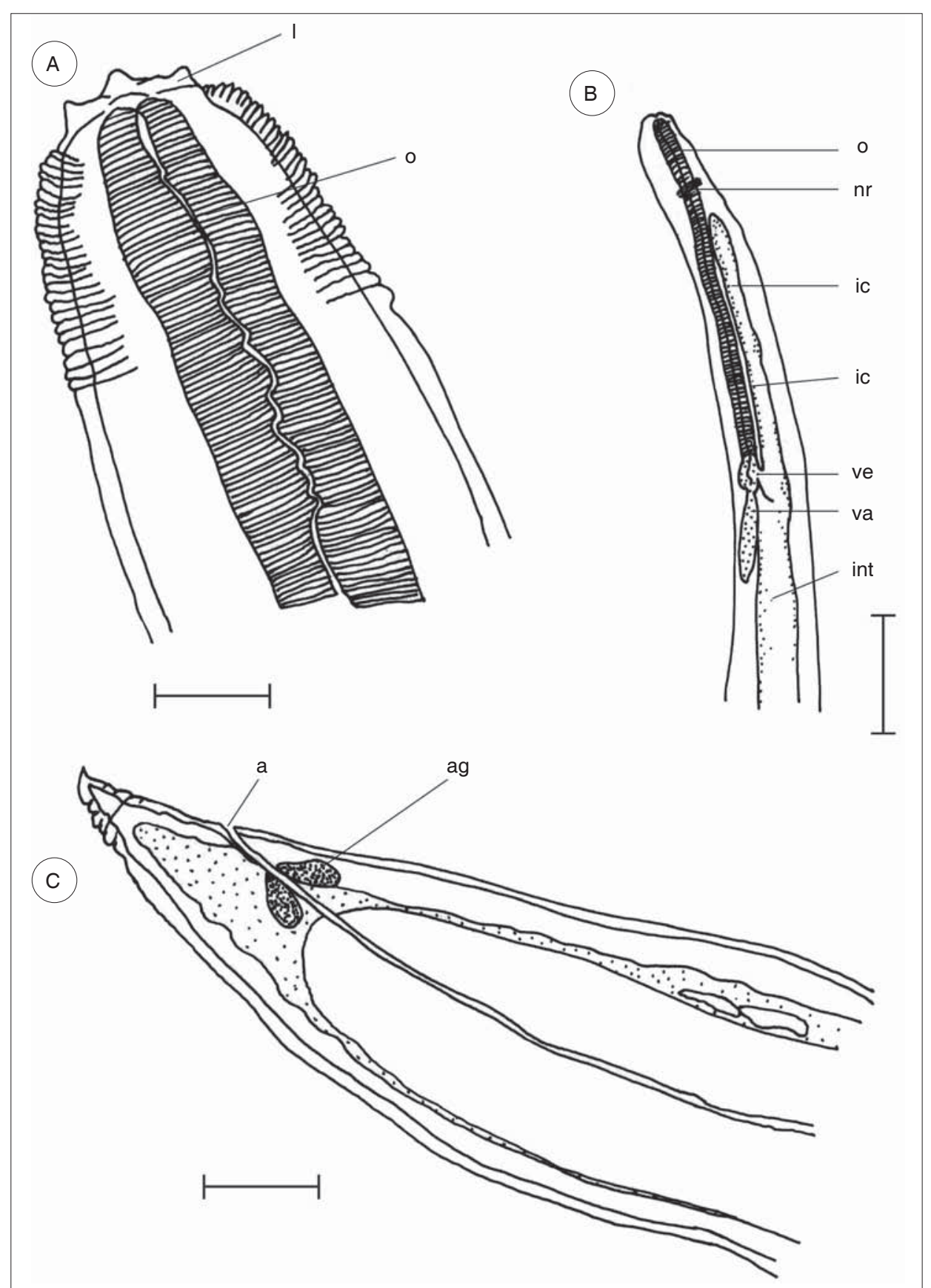

FIG. 4 Contracaecum sp. Larvae. (A) head. Scale bar $=200 \mu \mathrm{m}$; (B) anterior end showing ventricular region. Scale bar $=500 \mu \mathrm{m}$; (C) posterior end. Scale bar $=200 \mu \mathrm{m}$. a = anus, ag $=$ anal glands, ic = intestinal caecum, int = intestine, $\mathrm{I}=$ lip (labium), $\mathrm{nr}=$ nerve ring, $\mathrm{o}=$ oesophagus, $v a=$ ventricular appendix, ve $=$ ventriculus

camallanus infecting freshwater fishes have also been recorded in Europe (Moravec 1994) and in the Neotropical region (Santos et al. 1999).

\section{Contracaecum spp. larvae (Fig. 4)}

Third-stage larvae (L3) with two blind caeca branching off from the intestinal tract at the junction of the oesophagus and midgut (Fig 4B). Ventricular appendix shorter and pointing posteriorly; intestinal caecum longer and pointing anteriorly. Tail curved with terminal spine (Fig. 4C). Reproductive system not fully developed.

Contracaecum larvae have been recorded from catfish and other fish species from many water bodies 
in South Africa (Whitfield \& Heeg 1977; Mashego \& Saayman 1981; Boomker 1982, 1994a, b; Saayman et al. 1991), Zimbabwe (Chishawa 1991; Douëllou 1992; Barson 2004), and East Africa (Malvestuto \& Ogambo-Ongoma 1978; Aloo 2001). It is a cosmopolitan parasite of fish-eating birds and mammals (Hartwich 1974; Anderson 1992) and can reach alarming intensities without affecting the condition of the host (Mashego \& Saayman 1981; Boomker 1982; Paperna 1996), an adaptation that probably ensures that the larvae survive to reach the final host without killing the intermediate host.

Contracaecum larvae are difficult to differentiate into species except when using molecular analysis or alternatively infecting experimental hosts to obtain adult worms. Adult Contracaecum species from fish-eating birds have only been studied and recorded by Ortlepp (1938, cited by Mokgalong 1996), Saayman et al. (1991) and Mokgalong (1996) in South Africa. Canaris \& Gardner (1967) listed nine adult Contracaecum species from African waterbirds, while Barson \& Marshall (2004) recorded four species from Zimbabwean birds.

While a high prevalence ( $86 \%$ ) and a mean intensity of 16.3 (intensity range 3-44) were recorded from Rietvlei Dam, $100 \%$ infection levels are very common, with intensities as high as 700-2000 worms per fish (Mashego \& Saayman 1981; Boomker 1982, 1994a). This makes Contracaecum one of the most prevalent fish parasites in South Africa and the fact that its life cycle involves migratory bird species (e.g. cormorants) can justify this observation. Paperna (1996) urges aquaculturists to control aquatic birds on fishponds as an effective means of reducing Contracaecum infection.

\section{ACKNOWLEDGEMENTS}

We thank the University of Johannesburg and the Water Research Fund for Southern Africa (WARFSA) for funding this study, University of Johannesburg Zoology technical staff and student assistants for field and laboratory assistance, and SPECTRAU Unit and Graphics staff for technical support.

\section{REFERENCES}

ALOO, P.A. 2001. Occurrence of larval Contracaecum (Nematoda: Heterocheilidae) in three teleostean species from Lake Naivasha, Kenya. East African Journal of Science, 3:1-12.

ANDERSON, R.C. 1992. Nematode parasites of vertebrates: their development and transmission. Wallingford: CAB International.

AVENANT-OLDEWAGE, A. 2001. Protocol for the assessment of fish health based on the Health Index. Report and manual for training of field workers to the Rand Water Board. Vereeniging: Rand Water (Report no. 2001/03/31).

BARSON, M. 2004. The occurrence of Contracaecum sp. larvae (Nematoda: Anisakidae) in the catfish Clarias gariepinus (Burchell) from Lake Chivero, Zimbabwe. Onderstepoort Journal of Veterinary Research, 71:35-39.

BARSON, M. \& MARSHALL, B.E. 2004. First record of Contracaecum spp. (Nematoda; Anisakidae) in fish-eating birds from Zimbabwe. Journal of the South African Veterinary Association, 75:74-78.

BOOMKER, J. 1982. Parasites of South African freshwater fish. I. Nematodes of the catfish [Clarias gariepinus (Burchell, 1822)] from the Hartbeespoort Dam. Onderstepoort Journal of Veterinary Research, 49:41-51.

BOOMKER, J. 1994a. Parasites of South African freshwater fish. VI. Nematode parasites of some fish species in the Kruger National Park. Onderstepoort Journal of Veterinary Research, 61:35-43.

BOOMKER, J. 1994b. Parasites of South African freshwater fish. VII. Nematode parasites of some scaled fishes from the Hartbeespoort Dam, Transvaal. Onderstepoort Journal of Veterinary Research, 61:197-199.

CANARIS, A.G. \& GARDNER, S.L. 1967. A guide to helminth species described from African vertebrates. Morgantown: West Virginia University Library.

CHABAUD, A.G. 1974. Keys to subclasses, orders and superfamilies, in $\mathrm{ClH}$ Keys to the nematode parasites of vertebrates, edited by R.C. Anderson, A.G. Chabaud \& S. Wilmott. Slough: Commonwealth Agricultural Bureaux, 1:6-17.

CHISHAWA, A.M.M. 1991. A survey of the parasites of three Siluriformes [sic] fish species in Lake Kariba. Kariba: University of Zimbabwe (University Lake Kariba Research Station Bulletin, 1/91).

DOUËLLOU, L. 1992. A survey of fish parasites in Lake Kariba. Kariba: University of Zimbabwe (University Lake Kariba Research Station Bulletin, 1/92).

HARTWICH, G. 1974. Keys to genera of the Ascaridoidea, in CIH Keys to the nematode parasites of vertebrates, edited by R.C. Anderson, A.G. Chabaud \& S. Wilmott. Slough: Commonwealth Agricultural Bureaux, 2:1-15.

HOFFMAN, L.C. \& PRINSLOO, J.F. 1996. The potential of freshwater fish in South Africa. Food Industries of South Africa, 30: $1-2$.

KHALIL, L.F. 1970. On some nematodes from the freshwater fishes of Ghana with the description of a new species, Spironoura petrei $\mathrm{n}$. sp. Journal of Helminthology, 46:63-68.

KHALIL, L.F. 1991. Techniques for identification and investigative helminthology: Techniques for processing platyhelminths and acanthocephalans, in Helminthology manual, edited by L.F. Khalil. London: International Institute of Parasitology.

KHALIL L.F. \& POLLING, L. 1997. Check list of the helminth parasites of African freshwater fishes. Department of Zoology/ Biology. Sovenga: University of the North.

MALVESTUTO, S.P. \& OGAMBO-ONGOMA, A. 1978. Observations of the infection of Tilapia leucosticta (Pisces: Cichlidae) with Contracaecum (Nematoda: Heterocheilidae) in Lake Naivasha, Kenya. Journal of Parasitology, 64:383-384.

MARGOLIS, L., ESCH, G.W., HOLMES, J.C., KURIS, A.M. \& SCHAD, G.A. [1982]. The use of ecological terms in parasitology (Report of the American Society of Parasitologists). Journal of Parasitology, 68:131-133.

MASHEGO, S.N. 1977. A seasonal investigation of the ecto- and endoparasites of the barbel, Clarias gariepinus (Burchell, 
1822) in Lebowa, South Africa. M.Sc. thesis, University of the North, South Africa.

MASHEGO, S.N. 1982. A seasonal investigation of the helminth parasites of Barbus species in water bodies in Lebowa and Venda, South Africa. Ph.D. thesis, University of the North, South Africa.

MASHEGO, S.N. \& SAAYMAN, J.E. 1981. Observations on the prevalence of the nematode parasites of the catfish, Clarias gariepinus (Burchell, 1822), in Lebowa, South Africa. South African Journal of Wildlife Research, 11:46-48.

MOKGALONG, N.M. 1996. A study of the gastrointestinal helminths of the Phalacrocoracidae and the Anhingidae in the Northern Province, South Africa. Ph.D. thesis, University of the North, South Africa.

MORAVEC, F. 1975. The development of Procamallanus laevionchus (Wedl, 1862) (Nematoda: Camallanidae). Věstík Československé Společnosti Zoologické, 39:23-38.

MORAVEC, F. 1994. Parasitic nematodes of freshwater fishes of Europe. Prague \& Dordrecht: Academia \& Kluwer Academic Publishers.

OPARA, K.N. \& OKON, A.O. 2002. Studies on the parasites of cultured Oreochromis niloticus (Cichlidae) in a rainforest fishpond in South East Nigeria. Journal of Aquatic Sciences, 17: 17-20.

PAPERNA, I. 1996. Parasites, infections and diseases of fishes in Africa: An update (FAO/CIFA Technical Paper, no. 31).

PRUDHOE, S. \& HUSSEY, C.G. 1977. Some parasitic worms in freshwater fishes and fish predators from the Transvaal, South Africa. Zoologica Africana, 12:113-147.
SAAYMAN, J.E., MASHEGO, S.N. \& MOKGALONG, N.M. 1991. Parasites of the fish population with notes on the helminth parasites of the water birds of Middle Letaba Dam, in A post impoundment ecological study of the Middle Letaba Dam, Gazankulu, edited by J.E. Saayman, H.J. Schoonbee \& G.L. Smit. Pretoria: Department of Development Aid.

SAFRIEL, O. \& BRUTON, M.N. 1984. Aquaculture in South Africa: A cooperative research programme. South African National Scientific Programmes (Report no. 89).

SANTOS, C.P., CÁRDENAS, M.Q. \& LENT, H. 1999. Studies on Procamallanus (Spirocamallanus) pereirai Annereaux, 1946 (Nematoda: Camallanidae), with new host records and new morphological data on the larval stages. Memorias do Instituto Oswaldo Cruz, Rio de Janeiro, 94:635-640.

SKELTON, P.H. 2001. A complete guide to the freshwater fishes of Southern Africa. Cape Town: Southern Book Publishers.

WESSELS, V. 1998. Rietvlei's friends fight for wetlands. http:// www.boma.wildnetafrica.com.

WHITFIELD, A.K. \& HEEG, J. 1977. On the life cycles of the cestode Ptychobothrium belones and nematodes of the genus Contracaecum from Lake St. Lucia, Zululand. South African Journal of Science, 73:121-122.

YAKUBU, D.P., OMOREGIE, E., WADE, J.W. \& FARINGORO, D.U. 2002. A comparative study of gut helminths of Tilapia zilli and Clarias gariepinus from River Uke, Nigeria. Journal of Aquatic Sciences, 17:137-139.

YAMAGUTI, S. 1961. Systema Helminthum. Vol. III. The nematodes of vertebrates. New York \& London: Interscience Publishers, Inc. 